\title{
Indigenous Conflict Resolution and the Protection of Human Rights among the Talensi of Ghana
}

\author{
David Naya Zuure ${ }^{1 *}$, George Hikah Benson ${ }^{2}$, Adams S. Achanson ${ }^{3}$ \\ ${ }^{1}$ Centre for African Studies, University of Education, Winneba, Ghana \\ ${ }^{2}$ Department of Social Studies Education, University of Education, Winneba, Ghana \\ ${ }^{3}$ Faculty of Education, University for Development Studies, Tamale, Ghana \\ *Corresponding author: davidsonzuurich01@yahoo.com or dnzuure@uew.edu.gh
}

\begin{abstract}
Indigenous approaches to conflicts resolution in African societies provide appropriate fora and opportunities for members of the societies to process their disputes when they do arise. The indigenous approaches are structured and rooted on cultures and traditions of the societies in which they are applied. The Talensi traditional area has its indigenous approach based on its culture and tradition as well. However, there are concerns with regards to how indigenous approaches to conflict resolution recognize and respect the human rights of persons involved in the process. This paper examined how the Talensi indigenous conflict resolution approach recognizes and respects the human rights of the disputants. It was a qualitative research which employed the case study design. Two chiefs, three elders to chiefs' councils and five disputants were purposively and conveniently selected as sample for the study. The instruments in terms of interview, focused group discussion and observation were used to gather data for the study. It emerged from the study that the various considered human rights (rights to life, non-discrimination, freedom of religion and belief and prohibition of torture and other ill-treatment) of disputants were recognized and respected to a large extent under the Talensi indigenous approach to conflict resolution. It was, therefore, recommended that the approach is replicated in other rural societies in Ghana so as to ensure the recognition and respect for disputants rights as many people in rural Ghana practically rely on indigenous approaches to process their disputes.
\end{abstract}

Key words: Indigenous, Conflict Resolution, Human Rights, Protection

\section{Introduction}

The concept of conflict has received varied definitions in literature based on the context from which it is presented. Coser (1956) provides a classical definition of conflict as the struggle between opponents over values and claims to scarce status, power and resources. Wellensteen (2002) defines conflict as a situation in which two or more parties strive to acquire the same scarce resources at the same time. Barash and Webel (2002) on their part present conflict as a different perception or view to an issue or situation. It may also connote hostility or physical confrontation (Jeong, 2000). The concept of conflict, therefore, means different perspectives of motives. It can be noted that fundamental to the concept of conflict is scarce resources. Wallensteen (2002) has pointed out that resources are not only economic in nature, but includes, human security, environment, historical issues, etc.

African societies are continually faced with different forms of conflict. Among these conflicts are ethnic, land, chieftaincy, marital and inter-personal. Many African societies have fashioned and applied indigenous approaches to deal with such conflicts since conflicts must be resolved in order to prevent them from escalating into violent actions and the destruction of social harmony. These indigenous mechanisms are based on the social, economic, religious, political and cultural contexts of the 
people applying them (Gebre, 2011; Gabbert, 2014; Mac Ginty, 2014; Leonardsson and Rudd, 2015).

There are, however, some concerns over the use of indigenous mechanisms in the resolution of conflict when it comes to human rights. There are concerns that indigenous conflict resolution mechanisms inherently compromise human rights, particularly those of women children and other minorities (Okrah, 2003, Owusu-Mensah, Asante, \& Osew, 2015) such as the rights to own property, free expression and religion. The United Nations Commission on Human Rights (2017) also contends that the application of customary law can also do tremendous violence to others who lack power or authority under the traditional regime and those who have been historically disenfranchised, such as non-natives.

Indigenous conflict resolution in Africa takes different forms and are usually embedded in African customary laws and reflect norms and values (Kariuki, 2015). It involves the use of council of elders (men and women) who act as third parties in the processing of conflicts. In Rwanda, the Gacaca is employed to resolve conflicts where elders of families sit on grasses to guide the process. Also, the Tswana is used in Botswana where household heads, extended family heads and the customary court consisting of chief and paramount chief at the village and regional levels with their elders resolve conflicts. Similar institutions exist in Kenya and South Africa (Mac Ginty, 2014).

Indigenous conflict resolution mechanism in the Talensi area of Ghana involves the use of chiefs and their councils of elders. This approach to conflict resolution is very prominent in the area. The model, like similar mechanisms in other African societies, is a well- structured and time-proven social system with a strong focus on reconciliation, maintenance, restoration and improvement of social relationships of disputants (Naude, 2010; Murithi, 2009). The approach derives its legitimacy from the 1992 Constitution of Ghana which guarantees the institution of chieftaincy, together with its traditional councils as established by customary law and usage (Article 270), and the Chieftaincy Act, 2008 (Act 759) that empowers the chief with his elders to arbitrate on disputes (Section 30).

Like any society in modern times, the state-owned court system exists in the Talensi area of Ghana. The courts are manned by professionals who are trained, employed and paid by the state to resolve conflicts of people using the law. The court system recognizes fundamental human rights and freedom of persons using it and has prescribed procedures and processes that seek to protect the rights of disputants. As a result, disputants are procedurally and substantially protected against such abuses as discrimination on the basis of age, gender, social, religious and economic statuses; verbal abuse, suppression, etc (Oquaye, 2013). Unfortunately, few people in the Talensi area employ the courts to resolve their conflicts which the researcher presumes is due to geographical and financial inaccessibility as well as the fear of "justice-buying", power influence and manipulations. The Talensi traditional approach to conflict resolution is another option for people in the area to use and resolve their conflicts. This traditional approach is widely used in the area (Awedoba, 2014).

The focus of most researches on traditional conflict resolution has been on its nature, strengths and challenges (Awedoba, 2009; Boege, 2006); its usage in peacebuilding (Marfo, 2014; Bingpong \& Buta, 2013); the indigenous institutions used in the approach (Brock-Utne, 2006; Nwolise, 2005); and the mechanisms of the traditional conflicts disputing forum (Kirby, 2006). However, there is no scholarly knowledge on how the Talensi indigenous approach (using chiefs and elders) protects the rights of the disputants. This work, therefore, sought to explore how the Talensi indigenous approach to conflict resolution protects the human rights of the disputants.

The study was guided by the question "How does the Talensi indigenous conflict resolution mechanism protect the human rights of disputants?"

\section{Related Literature and Studies}

This presents the review of related literature and studies.

\section{Human Needs Theory}

The Human Needs Theory operates on the premise that all humans have basic needs which they seek to fulfill, and that the denial and frustration of these needs by other groups or individuals could affect them immediately or later. The theory, therefore, holds that a pre-condition for effective resolution of conflict is the recognition and respect for some basic needs of the disputants. The authors of this paper argue that human right is a basic need of all persons at all time, hence, for effective resolution of 
conflicts, the fundamental human rights of the disputants must be met. Burton and Sandole (1986) referred to what they called the "ontological needs" to develop the human needs theory along which they argue that ontological needs are a consequence of human nature, which are universal and should be pursued always. Azar (1994) opined that basic human needs include security, distributive identity, social recognition of identity and affective participation in the processes that shape such identities. Walsh (2016) contends that without a consideration to the human needs of disputing parties, effective resolution of the dispute is a dilution. Vayrnen (2018) on his part is of the view that one's culture is an essential need and should therefore be always recognized.

This theory requires that the resolution of any conflict must be done in a manner that would ultimately ensure that disputants feel that their respective basic needs are met at the end of the process. Human needs are varied and complex, therefore, the people who facilitate the process of resolving conflicts must be tactical enough to identify the specific needs desired by disputing parties over which the dispute emerged.

\section{Conceptualization of Human Rights}

Wiredu (1990), in his work "An Akan perspective on Human" defines human rights as the claims that people are entitled to make simply by virtue of their status as human beings. Frezzo (2014) describes human rights as a set of protection and entitlements held by all members of the human species irrespective of race, class, gender, sexual orientation, cultural background or national orientation. The concept of human rights acknowledges that every single human being is entitled to enjoy his or her rights without any distinction as to race, color, sex, language, religion, political or other opinion, national or social origin, property, birth or other status. Generally, human rights are commonly understood as being those rights which are inherent to the human being (CHRAJ, 2016). Indeed, our rights are claims we have by virtue of the fact that we are human beings rather than as citizens of a country.

These definitions reveal how human rights have universal legal guarantees that ultimately protect individuals and groups against actions which interfere with their fundamental freedoms and human dignity. Human rights and freedoms are fundamental to human existence. They are inherent entitlements that come to every person as a consequence of being human and are founded on respect for the dignity and worth of each individual. Certainly, if the precondition for human rights is to be a human being, then, the same entitlements and protections should be available to everyone across the world.

The authors of this paper opine that human rights are basic things, conditions or entitlements that protect our ability to satisfy our most needs in dignity and respect which stem from some natural capacities and capabilities in the nature of human beings. Hence, as human beings, we have the right to express ourselves because, in our nature, we have mouths with one of its natural functions being speech just as we have the right to move about because in our nature as human beings, we have legs which naturally are able to carry us around. Hence, our human rights are the things we have the capabilities or capacity to do as human beings, and so, all persons have human rights.

\section{Indigenous Conflict Resolution}

Indigenous conflict resolution in African societies exists at different levels right from the family through the clan and to the community levels. Traditional conflict resolution mainly involves using indigenous institutions, knowledge and ideas to deal with conflicts. Traditional conflict resolution is defined as the "capability of social norms and customs to hold members of a group together by effectively setting and facilitating the terms of their relationship. .....sustainability facilitates collective action for achieving mutually beneficial ends" (FredMensah, 2005, p. 2). It is a process in which stakeholders take conscious effort to work towards the management of a conflict with the main focus on re-establishing the flow of harmonious relationship within individuals, families and communities (Matthew, 2014). It is reconciliatory in nature which is often characterized with symbolic gestures and associated rituals including the exchange of gifts and slaughtering of animals such as chickens, goats, sheep and cows (Ndumbe III, 2001). Traditional conflict resolution focuses on creating and restoring the impaired relationship with God, the spirits, ancestors, family and neighbors as the case might be and $\mathrm{t}$ is a healing process (Mbiti, 1991; Mahama, 2010).

Conflicts must be understood in their social context, involving "values and beliefs, fears and suspicions, interests and needs, attitudes and actions, 
relationships and networks..." (Brock-Utne, 2006, p. 4). It is therefore essential to understand the root causes of conflicts so as to enable shared understandings of the past and present. The focus of conflict resolution especially from the indigenous perspective is as noted by Kendie and Bukari (2012), to mend the broken or damaged relationship, rectify wrongs and restore justice. Another aim is to ensure the full integration of parties into their societies again and to adopt the mood of co-operation. The overall objective of traditional conflict resolution is to avoid accusations and counter-accusations, settle hurt feelings and reach a compromise with a greater focus on helping improve the future relationship of the parties involved (Galaa \& Bukari, 2014).

The key players in traditional conflicts resolution depend on the level at which it is being handled. Some conflicts can be processed at the family level with family heads or at the community level with the chief and elders. The roles played by the key actors may change from time to time as the situations demand. This is because there is no standard model with indigenous conflicts resolution processes (Esia-Donkoh, 2012). Thus, the traditional conflict resolution approaches are flexible and dynamic and the whole process and content are influenced by the social context. The social situation of those involved is also important. Thus, the social surroundings feedback into or influence the process (Esia-Donkoh, 2012; Annan, 2013).

In some parts of Africa including the Talensi area in Ghana, when the agreement is reached through indigenous conflict resolution, it is usually shared with all parties including the general community. This social perspective on conflict transformation has general advantages including the shared understanding of the conflict. It also encourages harmony through active participation in the process by all parties (Brock- Utne, 2006). According to Okrah (2003), traditional society's process conflicts through internal and external social controls. The internal social controls use processes of deterrence such as personal shame and fear of supernatural powers. External controls rely on sanctions associated with actions taken by others in relation to behaviors that may be approved or disapproved. Indigenous conflict resolution mechanisms focus on the principles of empathy, sharing and cooperation in dealing with common problems which underline the essence of humanity (Murithi, 2009).
Generally, indigenous conflict resolution mechanisms in Africa involve the identification of the root cause of the problem and engaging all parties concerned to address the underlying issues. This usually ends with the guilty party(ies) acknowledging and accepting wrongdoing, which potentially leads to reconciliation. Usually, the process ends with either a compensation or just forgiveness (Brock- Utne, 2006; Murthi, 2006). The process of indigenous conflict resolution has to do with how indigenous structures and systems bring about actions intended to ensure peace at the individual and community level relationships. In this respect, conflict resolution procedures are generated from general cultural life and daily experiences of living.

Indigenous conflict resolution approaches in Africa are often criticized as being discriminative in nature especially among the vulnerable like children. For example, Opasina (2017) reported in his study that some people in Nigeria indicated a child of the commoner is not likely to get fair justice in the traditional system and that justice is sometimes delivered on the basis of "the son of whom you are". Again, in Madagascar, the indigenous practice of "Dina" has allowed for summary executions to be perpetrated based on its decisions. Under indigenous system in Somalia, families of murder victims have the right to choose between compensation and the execution of the perpetrators (Kariuki, 2015).

\section{Research Methodology}

The part highlights the methodogy employed for the study.

\section{Research Approach and Design}

The research approach employed for the study was qualitative. Qualitative studies emphasize on words rather than the quantification of data. Qualitative research approach allowed the researchers to observe the people in their own territories and interact with them in their own language and terms. As a result, the approach was participatory as it made the participants to be deeply involved in the research process (Bryman, 2004).

The qualitative approach was considered more appropriate due to the desire of the researchers to engage the participants in their natural setting to unearth details how the application of the Talensi indigenous recognizes and respects the human rights of disputants. The approach allowed for direct 
engagement with the participants in order to construct meanings from the interaction on how the approach specifically recognizes, respects, and protects the basic human rights/entitlements to dignity, worth and value.

In line with the qualitative approach, the case study design was employed in the study. Creswel (2009) describes a case study as one in which the researcher explores in-depth a program, an event, an activity, a process or one or more individuals. He added that a case study has open-ended questioning and reveals new or anticipated phenomenon and raises more issues through broad and open-ended inquiry. The Talensi indigenous conflict resolution mechanism was picked as a case to study how it protects the human rights of the disputants. This design allowed the researchers to examine in-depthly the Talensi traditional approach to conflict resolution and the promotion of the human rights of disputants it provides.

\section{Population and Sampling}

The target population for the study was all adult persons in the Talensi area of Ghana. Adult persons in the area were regarded as the right person to provide useful information about the indigenous conflict resolution and how it protects human rights of disputants. The accessible population, however, included chiefs, elders, and disputants in the Talensi traditional are.

The sample for the study consisted of chiefs, elders, and persons who had used the Talensi traditional conflict resolution approach to process their disputes (disputants). Two chiefs, three elders and five disputants were involved in the study. These were selected through purposive and convenient sampling techniques. The chiefs, elders and disputants were purposively determined to be the people with the right information for the study. Subsequently, convenient sampling technique was used to select the two chiefs, three elders and five disputants to participate. The chief and elders were considered key informants as they were the people who manned and administered the approach in the area. The disputants were seen as people who have had first-hand experiences with the application of the approach, hence, were well placed to share those experiences as with regards to disputants' human rights protection to enrich the study.

Purposively, the chief, elders and disputants in the area were regarded as persons with the relevant knowledge, ideas, experiences and views that served the purpose of the study. Through convenient sampling, the chief, two disputants, and five disputants were selected from all the chiefs, elders and disputants in the area. Through the assistance of chiefs and elders in the various places in the area, a number of persons who used the traditional approach to process their disputes were identified and five of them were conveniently selected.

\section{Research Instruments}

The instruments in terms of interview guide, focused group discussion and observation were used to gather data from the respondents. The interview guide contained items that focused on how selected human rights of disputants were treated during the process of resolving disputes with the traditional approach. This instrument allowed the researchers to get engaged with the respondents in detailed discussions on the Talensi traditional conflict resolution approach and human rights protection as they were able to ask follow-up questions that provided direction for effective discussions on the topic and, hence, the collection of relevant data. Each respondent was met on oneon-one basis based on agreed date, time and venue. The focus group discussion brought together two elders and two disputants to share their ideas on how the Talensi indigenous conflict resolution respected the human rights of disputants. One of the researchers personally observed the process of resolving conflict using the Talensi indigenous approach to identify signs, symbols, gestures, languages and acts that showed recognition and respect for the rights of disputants through the process.

\section{Analysis and Results}

This part presents findings on how the Talensi indigenous conflict resolution model protects human rights of the disputants.

\section{Right to Life}

The right to life is unarguably the key of all human rights and has been protected by various human rights instruments and constitutions. The United Nations Charter on Human Rights (1945), International Covenant on Civil and Political Rights (1966), African Charter on Human and Peoples Rights (1981) and Republican Constitution of Ghana (1992) all guaranteed the right to life. The chiefs and elders in the Talensi area indicated that they cannot under any circumstance put any person's right to life to harm. They pointed out that their authority 
was for protection but not for harm. One of the Chiefs expressed it as follows:

I am only a human being with flesh and blood like all others. It is only God who gives and takes life and so, therefore, I cannot under any circumstance through my word, action, inaction or supervision allow for anything that will harm the life of a fellow human being. I and all chiefs have no power to harm a person's life. Every person's life is as valuable and precious as mine and should not be harmed. It is the Almighty God, our ancestors and nature that can harm a person's life.

Similarly, a disputant indicated that:

Our tradition has a great value for human rights of people. It recognizes the sacredness of life which is only given by God, hence, the traditional approach sufficiently upholds the rights of disputants. How would I get up and carry myself with my own legs to where my life can be harmed by my own leaders in the name of resolving a conflict? Then it would be better we live with our disputes than trying to resolve them.

These expressions reveal that the Talensi traditional approach recognizes and values the right to life of disputants. This approach is, therefore, unlike the case in Madagascar where there exist a system of customary justice known as "Dina" through which summary executions had been perpetrated based on its decisions and also the customary practice in Somalia where families of murder victims have the right to choose between compensation and the execution of the perpetrators. This makes the approach relevant as it is in tune with the United Nations Charter on Human Rights (1984), International Convention on Civil and Political Rights (1966), African Charter on Human and People's Rights (1986), and the Republican Constitution of Ghana (1992) which guarantee the right to life.

\section{Freedom of Religion or Belief}

Article 8 of the African Charter on Human and Peoples' Rights provides for religious freedom for people in Africa. The United Nation Charter on Human Rights similarly provides in Article 18 that everyone has the right to freedom of thought, conscience and religion among others, to manifest his or her religion or belief in teaching, practice, worship, and observance. The Talensi approach to conflict resolution allowed for individuals to enjoy their freedom of religion or belief. From the focused group discussion, one of the elders indicated this fact as follows:

The indigenous approach to conflict resolution is a customary practice but not a religious one. The people in the Talensi area who use this approach to resolve their conflicts belong to different religions. Therefore, the process in itself is neutral to religion and everyone appearing here is free to manifest any religious belief. No reference is made to any religion here and no limitation is put on anyone who wishes to manifest any religious faith and belief; every religion is permitted.

One Disputant expressed his view on the indigenous approach to conflict resolution and freedom of religion or belief as follows:

I can tell you from my experience that the traditional court does not in any way abuse or even threaten the belief systems and practices of anybody who appears there. When I appeared before the court, there was no instance where a particular religion's practice or doctrine was imposed or suppressed. When I wished to refer to part of the Bible as a Christian to explain my actions, I was told to feel free to exhibit my religious beliefs and that the focus of the process was purposely to determine the merits of the case.

The views of the elder and disputant above reveal that the approach respected disputants' freedom of religion. This finding is in line with the Republican Constitution, 1992 of Ghana as contained in Article 21(c) which states that all persons have the freedom to practice any religion and to manifest such practice. The finding further indicates an awareness of a distinction between a cultural practice and a religious practice. Some people, especially the Charismatic and Pentecostal church 
members, in the Talensi area, erroneously equate customary or cultural practices to African Traditional Religious practices and proceed on that wrong assumption to condemn the cultural practices of the area describing them as barbaric, fetish and devilish. It is on the basis of this background that the view expressed by the Chief below is very appropriate when he was asked if the Talensi traditional approach to conflict resolution allows for expression of religious beliefs by disputants.

Absolutely yes!!! At no time have
we considered religious belief and
practice as an issue here.
Unfortunately, some people
confuse cultural or customary
practices with African Traditional
Religious practices. Cultural
practices are different from African
Traditional practices. Neither sitting
down on the floor to greet a chief
nor clapping your hands when the
chief is speaking is African Religious
practice. These are cultural!!! The
Talensi people have a culture which
we put to practice here and we do
not prevent anyone from
manifesting any faith here [A Chief].

It can be seen from the above expressions that the Talensi approach to conflict resolution recognizes disputants' freedom to religious belief and practice. This is similar to what happens in state courts system where persons appearing are made to swear according to his or her faith and make references or comments that are attributive to his or her faith.

\section{Right to Equality and Non-discrimination}

Due to the unwritten nature of most customary laws in African societies, it is generally claimed that they tend to reinforce existing power relations in communities and, in some cases, may discriminate against certain groups. Many have argued that even if the structural and procedural aspects of customary laws are not in themselves discriminatory against persons belonging to certain groups, their application may be. How the Talensi traditional approach dealt with equality and non-discrimination was therefore explored.

It was noticed that discrimination with the Talensi approach could manifest with the procedure and with the nature of judgment. The chief and elders indicated that the procedure and judgments given on cases brought were not influenced by any other factor than the merits. They contended that all cases were taken through the same procedures and decisions reached based on the evidence provided by parties to the dispute. The chiefs and elders indicated that the homogeneity nature of the Talensi traditional area limits discrimination to a large extend. The Chief expressed this with the following words:

We apply the rules, procedure and approaches to all disputants before us in this court. We don't discriminate against anyone as to whether they are males or females, young or old, rich or poor, educated or uneducated, couple or close relatives, natives or foreigners and first time or more than first time appearance. The focus at all time is to establish the truth, serve justice, maintain peace and restore the relationship.

Specifically, on discrimination against women, the chief, elders and disputants pointed to the fact that the approach was impartial and did not discriminate against women. The following statement by a female disputant in an interview summarizes:

I am a woman but I can say that with my knowledge and personal experience of the approach, it does not discriminate against women when it is being applied. The procedure for resolving a conflict is established and all cases regardless who is involved are taken through that same established procedure. By subjecting every disputant to the same procedure, the truth emerges. If you are a man or woman and you have a bad case, the process will expose you and if you are a woman with a good case, the process will exonerate you. Who can hide the truth with this process which is very transparent because you are a woman? When it comes to the sanctions, the approach is neutral and impartial because it is often the forfeiture of the filing fee.

The data from the chief, elders, and disputants indicated that the Talensi traditional process to conflict resolution is positive in the light of the non- 
discrimination clauses of the International Covenant on Civil and Political Rights (1966) and the Convention on the Elimination of All Forms of Discrimination against Women's (1979) bans on discrimination on the basis of sex.

Also, the findings from the chief and elders indicated that the Talensi traditional approach to conflict resolution provides equal grounds for children to have their conflicts resolved favourably as all cases are taken through the same procedure and processes. An Elder said:

We know that our children today are those who by tomorrow will be in charge of affairs and we owe it a responsibility to train them to become capable adults. As part of our responsibility to our people, we are required to be fair to them and protect them to make them feel they are human beings and have what it takes to be successful and make a difference. As a result, as much as possible, we don't say or do anything that will subject the child to emotional or physical torture or those which will make them feel degraded.

The chief pointed out that:

Children are among the vulnerable in our society and we with the authority have to protect them but not to abuse them. We recognize their immaturity, so we rather protect and also charge their parents to train them properly to grow into useful adults.

Similarly, a Disputant during the focus group discussion expressed how the approach protects children as follows:

When my son had a case with our neighbor and we appeared before the traditional court, there was no discrimination in the process of settling the case. They were both taken through the same procedure and given equal opportunities to present their sides of the dispute for fair settlement. My son was given significant respect and value.
In the Talensi area, a child involved in case normally appears at the traditional court for proceedings with a member or members of his or her family and the focus tends to be on reparation, reconciliation and ensuring the child remains part of the community. This finding disagrees with Opasina (2017) when he found that some people in Nigeria indicated a child of the commoner is not likely to get fair justice in the traditional system and that justice is sometimes delivered on the basis of "the son of whom you are." The Talensi traditional conflict resolution approach tends to be more available to children and their families and provide for less formal means of conflict resolution than the formal courts as it uses more accessible language, has a greater potential for healing and is less costly.

\section{Prohibition of Torture and Other Forms of III- treatment or Punishment}

The International Covenant on Civil and Political Rights (1966) provides that "No one shall be subjected to torture or to cruel, inhuman or degrading treatment or punishment" (Art. 7). This to a very large extent is respected with the traditional approach to conflicts among the Talensi people. The chief contended that torture, cruel, inhuman and degrading treatment were not used with the Talensi traditional justice system. All the chief and elders indicated that the sanctions or punishment with the Talensi traditional conflicts resolution was mainly the forfeiture of the filing fee, animals and money. The Chief had this to say concerning torture and other ill-treatment with the traditional approach:

No torturous and humiliating
actions such as beating are given. As
a chief, I am a father to everyone
and must care for all. If I allow for
such things, others will certainly
abuse it which can lead to harm or
death and I will be held responsible.
Therefore, our sanctions end with
the filing fee, fine of money,
animal(s) or a combination.

This was corroborated by disputants who have used the traditional approach through the interview:

Our forefathers had great wisdom and appropriate value for humans. Our traditional approach to conflict resolution from the beginning to the end has no humiliating, dehumanizing, degrading or torturous elements. Parties to a

8 East African Journal of Education and Social Sciences (EAJESS) 1(3)1-11 
dispute are assisted by being taken through the process for them to settle their differences. In the end, they share food and drinks before leaving for home. Even the one who is determined to have been at fault only forfeits the filing fee and if the offence is grief, a little fine is added.

This finding presents a different perspective which contrasts the report of the Human Rights Committee of the United Nations where they found other forms of ill-treatment such as corporal punishment used by traditional justice systems in some parts of Africa. This violates the Covenant on Civil and Political Right's prohibition of cruel, inhuman and degrading treatment or punishment. It must, however, be noted that, historically, corporal punishment in the form of whipping has been used by the Talensi traditional justice approach as with other traditional justice systems in Africa as was reported by the chief.

On banishment, the chiefs and elders indicated that it was one options of sanction strictly for notorious witches and wizards. They, however, said that this was rarely used. This practice constitutes cruel, inhuman and degrading treatment or punishment and hence violates the Article 12 of the International Covenant on Civil and Political Rights (1966provides that "everyone lawfully within the territory of a State shall, within that territory, have the right of liberty of movement and freedom to choose his residence."

\section{Conclusions and Recommendations}

This part gives the conclusions of the study and then presents the corresponding recommendations.

\section{Conclusions}

The finding of the study as examined under the various sub-themes as right to life, freedom of religion. right to equality or non-discrimination and freedom from cruel, inhumane and other illtreatment or punishment reveal that the Talensi traditional conflict resolution approach very much recognizes, respects and protects the human rights of disputants. This is in line with the view expressed by Elechi (2004) that with African indigenous justice system, the rights of the victim, offender and the community are respected and protected. Findings from his study indicate that the restoration of rights, dignity, interests and wellbeing of victims, offenders and the entire community is the goal of the Talensi indigenous justice system.
The Talensi indigenous approach provides a good opportunity for conflict resolution and the achievement of justice. This is partly due to the fact that the central principle of the approach is empowerment of victims, offenders and the community. As a victim-centred justice system, the first priority of Talensi justice is the safety of victims. Assistance is given to victims to restore their injury, property lost and their sense of security and dignity. Again, the victims' needs for information, validation, social support and vindication are the starting points of the Talensi justice approach.

\section{Recommendations}

The Talensi indigenous approach to conflict resolution does protect and promote the human rights of disputants. This is largely due to its focus on restoring relationships between disputing parties. It is, therefore, recommended that the principles that govern the application of the approach should be applied to many other traditional institutions in the Talensi area to enhance the traditional institution's' protection of the rights of people. It is further recommended that the chiefs and elders in the Talensi area who administer the indigenous conflict resolution processes be given further training on contemporary elements of human rights so as to make them recognize and protect them. The Talensi indigenous approach to conflict resolution should be replicated in other rural societies in Ghana so as to ensure the recognition and respect for disputants' rights as many people in rural Ghana practically rely on indigenous approaches to process their disputes.

\section{Reference}

Annan, N. (2013): Providing peace, security and justice in Ghana: The role of non-state actors. Policy Brief. Accra: KAIPTC.

Awedoba. A. K. (2014). The peoples of northern Ghana. Accra: National Commission on Culture.

Azar, E. (1994). Protracted international conflicts: Ten prepositions in Rabie, M. Conflict Resolution and Ethnicity. London: Praeger.

Bimpong-Buta, S.Y. (2013). Essential requirements of customary arbitration. Daily Graphic, 14 November, 2013, p. 10.

Boege, V. (2006). Traditional approaches to conflict transformation-Potentials and Limits. Berghof Research Center for Constructive Conflict Management 
Barash, D.P. and Webel, C.P. (2002) Peace and Conflict Studies (Thousand Oaks, CA: Sage Publications).

Brock-Utne, B. (2006). Indigenous Conflict Resolution in Africa. Paper Presented at the Weekend seminar on Indigenous Solutions to Conflicts, 23-24 February. University of Oslo.

Bryman, A. (2004). Social Research Methods. New York: Oxford University Press, Inc.

Burton, J. W. \& Sandole, D. J. D. (1986). Generic theory: The basis of conflict resolution. Negotiation Journal, Vol. 2(4).

Coser, L. (1956). The functions of social conflict. Philadelphia: The Free Press.

Creswell, J. W. (2009). Research designs: Qualitative and quantitative approaches. Thousand Oaks: Sage

Elechi, O. O. (2004). Human rights and the African indigenous justice system(A paper for presentation at the 18th International Conference of the International Society for the Reform of Criminal Law, August $8-12$, 2004, Montreal, Quebec, Canada.

Esia-Donkoh, K. (2012). Traditional conflict resolution in the Ghanaian context. In Eric Sakyi Nketiah (ed), Distance Forum Vol. (2). Abossey Okai: Defalis Concept.

Fred-Mensah, B. (2005). Nugormesese: An indigenous basis of social capital in a West African community. $1 \mathrm{~K}$ Notes, No. 86. World Bank.

Frezzo, M. (2015). Sociology of human rights. Cambridge: UK Polity Press.

Gabbert, C. E. (2014). The global neighborhood concept: A chance for cooperative development or Festina Lente. In A delicate balance, land use, minority rights and social stability in the Horn of Africa edited by Mulugeta G. Berhe. Addis Ababa: Institute for Peace and Security Studies, Addis Ababa University.

Galaa, S., \& Bukari, F. I. M. (2014). Water Tariff Conflict Resolution through Indigenous Participation in Tri-Water Sector
Partnerships: The Case of Dalun Cluster Communities in the Northern Region of Ghana. Development in Practice, 24(5-6), 722-734.

Gebre, Y., Fekade A., and Assefa, F. (2011). Customary dispute resolution mechanism in Ethiopia. Addis Ababa: The Ethiopian Arbitration and Reconciliation Center.

Jeong, H. (2000) Peace and Conflict Studies: An Introduction (Aldershot: Ashgate).

Kendie, S. B., \& Bukari, K. N. (2012). Conflict and its effects on the development of the Bawku traditional area. University of Cape Coast Journal of Arts and Social Sciences, 1(1), 190 $-211$.

Kariuki, F. (2015). Conflict resolution by elders in Africa: Successes, challenges and opportunities. Retrieved from: www.ciarb.org/docs/defaultsource/centena rydocs/speaker-assets/francis-kariuki .pd f?sfvrsn=0:

Kirby, J. P. (2006). The earth cult and the ecology of peace building in Northern Ghana. In: Millar David (ed), African Knowledge and Sciences. London: ETC/COMPAS, ZED Books. Pp 12948.

Leonardsson, H. and Rudd, G (2014). The 'local turn' in peacebuilding: A literature review of effective and emancipatory local peacebuilding. Third World Quarterly, Vol. $36(5)$.

MacGinty, R. (2014). Everyday peace: Bottom-up and local agency in conflict -affected societies. Security Dialogue, Vol. 45(6), 548 -564 .

Mahama, E. S. (2010). Conflict in Ghana: strategies, stakeholders and the way forward. In B. S. Kendie (ed.) (2010). Proceedings of the 2010 harmattan school: conflict management and peace building for poverty reduction. Tamale: Center for Continuing Education and Inter-disciplinary Research, University for Development Studies.

Marfo, S. (2014). Indigenous Ghanaian conflicts resolution and peace-building mechanism, reality or illusion: A reflection on funeral among the people of Apaah and Yonso in 
the Ashanti Region. Online Journal of African Affairs, 3 (8), 124-133.

Matthew, J. (2014). Troop force triple in Ferguson as Obama condemns violence. Yahoo News, November 25, 2014.

Mbiti, J. 1991. Introduction to African religion. Oxford: Heinemann.

Murithi, T. (2009). Practical peace making wisdom from Africa: Reflections on Ubuntu. The Journal of Pan African Studies, Vol. 1(4), pp.25-34.

Naude, W. (2010) Development progress in Sub Saharan Africa: Lessons from Botswana, Ghana, Mauritius and South Africa. Working Paper No. 2010/07. Helsinki, Finland, United Nations University and World Institute for Development Economics Research.

Ndumbe III, K. (2001). The spiritual dimensions of conflict resolution mechanisms in African countries. University of Oslo, Unit for comparative and International Education, Institute for Educational Research, Accessed 23/02/2016.

Nwosile O.B. (2005). Traditional models of bargaining and conflict resolution in Africa: Perspective on peace and conflict in Africa. Ibadan: John Archers Ltd.

Okrah, K. A. (2003). Towards global conflict resolution: Lessons from the Akan traditional judicial system". Journal of Social Studies Research, fall. Retrieved from: http:www.findarticles.com/p/articles/mi_qa 3823/is_200310/ai_nq304242. Accessed on: $12^{\text {th }}$ June, 2017.

Opasina, O.K. (2016). Traditional institutions and the challenge of modernity in Nigeria and Côte d'Ivoire. International Journal on World Peace", 33(2), 43-75.

Oquaye, M. (2003). Democracy and conflicts resolution in Ghana. Accra: Gold-Type Publications Ltd.

Owusu-Mensah, I. Asante, W and Osew, W. K. (2015). Queen mothers: The unseen hands in chieftaincy conflicts among the Akan of
Ghana: Myth or reality? The Journal of Pan African Studies 8(.6)

Wallensteen, P. (2002). Understanding Conflict Resolution War, Peace and The Global System. London: Sage Publishing.

Walsh, D. (2016). How a Human Needs Theory Understanding of Conflict Enhances the Use of Consociationalism as a Conflict Resolution Mechanism: The Good Friday Agreement in Northern Ireland, Ethnopolitics, 15:3, 285302, DOI: 10.1080/17449057.2015.1024012

Wiredu, K (1990). The Akan perspective on human rights. In: An-Na'im and Deng (eds), Human rights in Africa: Cross-cultural perspectives. Washington D.C: The Brookings Institution.

The Constitution of the Forth Republic of Ghana (1992). Accra: Assembly Press. The African Charter on Human and People Rights (1981). In Sandy Ghandhi (ed), International human rights documents (6 ${ }^{\text {th }}$ edition). New York: Oxford University Press.

The Chieftaincy Act (2008), Act 759. Accra: Assembly Press.

United Nations Commission on Human Rights (2017). Annual Report. In: Sandy Ghandhi (ed), International human rights documents ( $6^{\text {th }}$ edition). New York: Oxford University Press.

United Nations Convention on Civil and Political Rights (1966).

United Nations Convention on Elimination of all Forms of Discrimination against Women (1979).

United Nations Charter on Human Rights (1945). In: Sandy Ghandhi (ed), International human rights documents $\left(6^{\text {th }}\right.$ edition). New York: Oxford University Press.

Vayrynen, T. (2018). Burton' human needs theory and the denial of culture in conflict resolution. Culture and International Conflict Resolution, DOI: http://doi.org/10.7765/9781526130990.000 06. 